\title{
Catholic Churches and Dwelling Temples: An Isomorphic Study of Construction Techniques on Early Catholic Churches and Vernacular Dwellings in East Fujian, China (1840-1900) - A Secondary Publication
}

\author{
Youli Zhu \\ School of Urban Construction, Yangtze University, Jingzhou, Hubei Province, China
}

Corresponding author: Youli Zhu, School of Urban Construction, Yangtze University, Jingzhou, Hubei Province, China. Email: zhuyouli81@qq.com

Citation: Zhu Y, 2021, Catholic Churches and Dwelling Temples: An Isomorphic Study of Construction Techniques on Early Catholic Churches and Vernacular Dwellings in East Fujian, China (1840-1900) - A Secondary Publication. Journal of Chinese Architecture and Urbanism, 3(2): 1241. http://dx.doi.org/10.36922/jcau.v3i2.1241

\begin{abstract}
This paper attempts to examine the typologies of early Catholic churches in East Fujian Province, China, and analyze how they were internally relevant to local vernacular buildings. Focusing on the connection of architectural typology, this paper investigates the origination of the internal relevance, the Chinese path of Catholic church typological development, and the patterns of building techniques for Catholic churches in China. The conclusion indicates that both the early Catholic churches in East Fujian Province and local vernacular buildings were based on traditional Chinese craftsmanship, and therefore were isomorphic in their building forms. In the meantime, those early churches which hybridized traditional Chinese and Western architectural elements were typologically different from those "Chinese style" churches built in the Sinicization period of Christianity. This study contributes to enhancing the broadness and depth of the understandings of early Catholic churches in China.
\end{abstract}

Keywords: Catholic church, vernacular buildings, traditional craftmanship, architectural isomorphism, building-within-building

This article belongs to Secondary Publication Section, and is translated by Associate Professor Xiao Hu from an article published in Journal of Architecture History 《建筑史学刊》. Citation of primary version: Zhu Y, 2021, Isomorphism of Catholic Churches and Vernacular Architecture in Eastern Fujian During the Early Modern Period (1840-1900), 2(1): 100-109. http://dx.doi.org/10.12329/20969368.2021.01010

Copyright: (C) 2021 Journal of Architecture History. This is an open-access article distributed under the terms of the Attribution-Non-Commercial 4.0 International 4.0 (CC BY-NC 4.0), which permits all non-commercial use, distribution, and reproduction in any medium provided the original work is properly cited. 


\section{INTRODUCTION TO CATHOLIC CHRISTIANITY AND ITS CHURCHES IN THE EAST FUJIAN REGION}

In 1624, Giulio Aleni, an Italian Jesuit missionary and scholar from the Society of Jesus, a Catholic organization based in Rome, arrived at Fuzhou, China, becoming the first Christian Missionary in Fujian Province. He took the "conforming to local practices" approach in his missions and established a Catholic teaching system centered at Fuzhou, which later engaged all eight local administrations of the whole Fujian Province. This brought about the preliminary foundation of the Society of Jesus's missionary in Fujian. In the early 17th Century, the Roman Curia started to approve some Mendicant churches' missionaries to the regions where the Society of Jesus had actively engaged, in an attempt to break its monopolization of Catholic missions in China. Since then, several other Catholic groups, such as the Dominicans, Franciscans, and the Society of Foreign Missions of Paris, began to build their bases in East Fujian, which partially caused Chinese Rites Controversy. ${ }^{1}$ In 1707, the Roman Curia designated the Dominicans to be the only group in charge of Catholic missions in the whole Fujian Province, which eventually made the Dominicans the dominant Catholic group in this region. In the following few years, all other Catholic groups started to withdraw ${ }^{2}$, and the Dominicans finally became the only Catholic group retained in East Fujian.

In 1696, the Roman Catholic Archdiocese of Fujian established two bishop's offices at Muyang and Xitian, both at Fu'an. In the following two centuries, Fu'an had remained as the primary Catholic center of the whole province of Fujian. The First Opium War in 1840 and following wars between China and the West made foreign Christian groups gain significant influences in China. With the protection of Western military powers and the "unequal treaties and agreements" signed between the Western forces and China, Christian missions by the Western missionaries became more aggressive in China. The Roman Catholic Archdiocese of Fujian in 1883 established two apostolic vicariates: the Northern Fujian Vicariate and the Southern Fujian Vicariate. The northern regional bishop's office moved from Fu'an to Fuzhou, administering the Apostolic Vicariate of Northern Fujian, including all religious affairs within the Fu'ning Region ${ }^{[1]}$. In December 1923, the Ningde and Fu'an Regions were separated from the Apostolic Vicariate of Northern Fujian to form the Apostolic Vicariate of Fu'ning. Two years later, a temporary bishop's office was established in Luojiang, Fu'an. The main bishopric office was moved to Dingtou, Fu'an in 1927, and later to Sandu'ao, Ningde in 1928. The Catholic church hierarchy in China was finally formed in April 1946, which led to the promotion of Apostolic Vicariate of Fu'ning as the Diocese of East Fujian (Fu'ning). Until the founding of the People's Republic of China in 1949, this diocese administered a large Catholic network within all towns and villages of six deaneries, including Fu'an, Muyang, Xizhen, Luojiang, Ningde, and Xiaopu.

The first Catholic church in East Fujian was developed by Angel Cocchi, a missionary from Spanish Dominicans, through renovating a local dwelling after he arrived at the Xidong, a village in Fu'an county in 1631 ${ }^{[2]}$. According to a report in 1950 , there were

\footnotetext{
${ }^{1}$ Mendicants strongly disagreed on Matteo Ricci's approach that had been adopted by the Society of Jesus for a long time and brought the internal dispute between Roman Catholic Missionaries and the religiosity of Confucianism \& Chinese rituals into formal Chinese imperial institutions. This led to an over 120 years ban of Christian Missions in China by the Imperial Court. During this period, Catholic missions in China went into underground.

${ }^{2}$ The Society of Foreign Mission of Paris stopped its missions in Fujian in 1707 when its mission administrator Charles Maigrot was expelled from China and its last missionary hiding in Muyang was finally transferred to Sichuan. In 1772, the Franciscans sent its last missionary to Fujian, who died of sickness 5 years later. This terminated the mission of Franciscans in Fujian. Since then, the Spanish Dominicans had controlled the Catholic missions in East Fujian until the founding of the People's Republic of China in 1949.
} 
totally 71 Catholic churches, including 21 Parish churches and 50 non-Parish churches within the six deaneries ${ }^{[3]}$. Although most of these churches had been renovated or rebuilt due to damages caused by numerous antimissionary riots, natural disasters, and building refunctioning during the ban of
Catholic missionary, ${ }^{3}$ there were a number of old Catholic churches survived till today, all of which were built by Spanish Dominicans. These churches, except the Lankou Church, ${ }^{4}$ were located around the Lang Creek (Fu'an Creek) drainage basin, making them easily accessed from the coast ${ }^{5}$ [Figure 1].

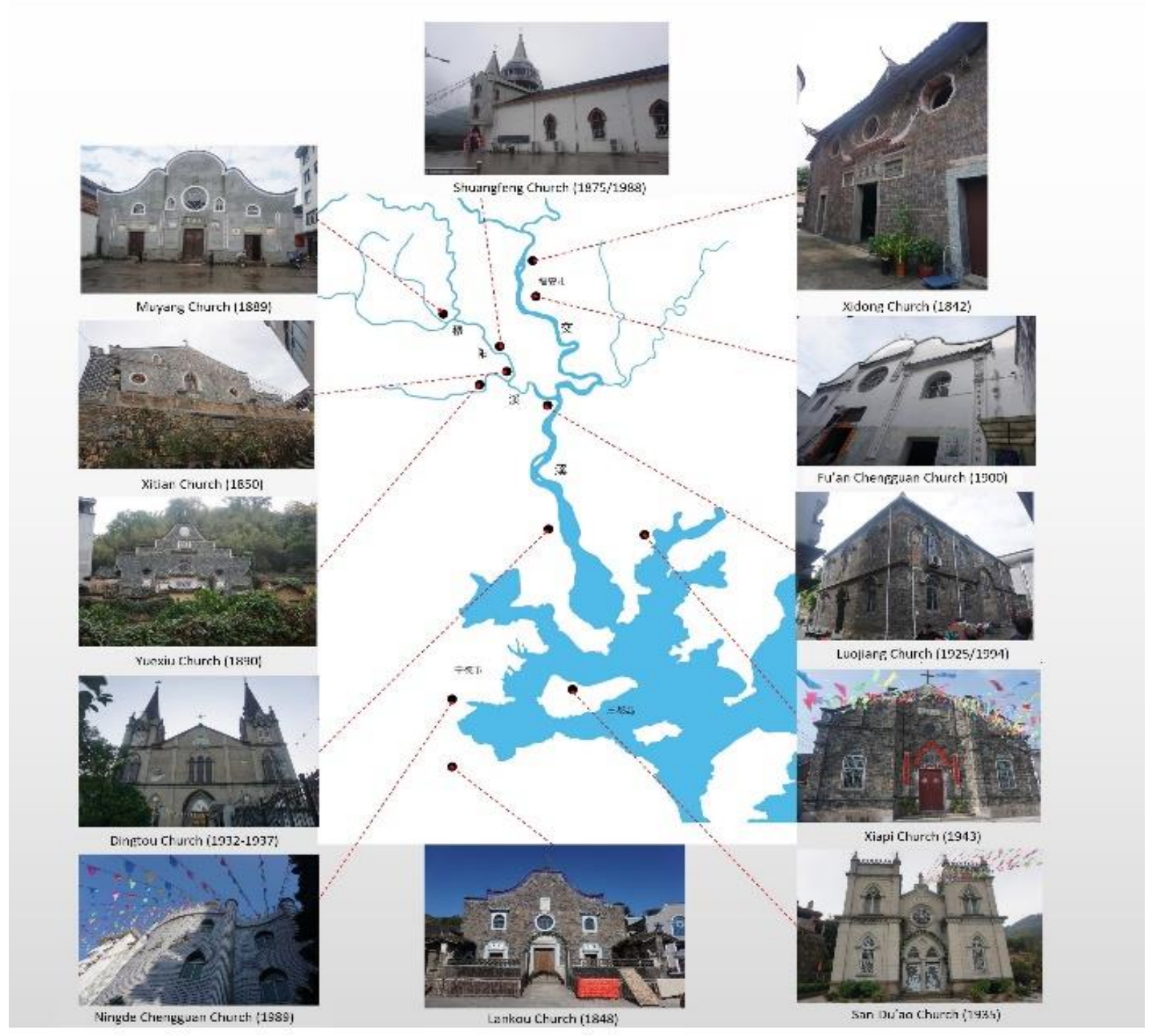

Figure 1. The geographic locations of Catholic churches in East Fujian. Source: Illustration and photos by the author

\footnotetext{
${ }^{3}$ Some churches were destroyed by anti-missionary riots, such as the Xidong Church destroyed by a riot in 1837, and the Muyang Church, which was destroyed and rebuilt twice between 1866 and 1877 and was rebuilt again in 1889 by the military protection of the Qing Court. Some were destroyed by typhoons, like the Qitou Parish Church by the No. 14 Typhoon in 1966, the Kangcuo Parish Church by a hurricane in August 1958. ${ }^{4}$ The Lankou Church was used many times as a safety shelter during anti-missionary riots due to its unique location on the top of a hill. Hence, it was called "the safety shelter of the Archdiocese of Fujian."

${ }^{5}$ Sandu'ao started international trade in May 1899 and became a transshipment port for Fuzhou, making it the third major trading port in Fujian besides Xia'men and Fuzhou. This contributed to the location change of Catholic center in East Fujian.
} 
Presenting similar building envelopes with local dwellings, many of these Catholic churches demonstrated noticeable features of traditional Chinese architecture with the adoptions of local building materials and traditional construction techniques, such as hollow masonry walls, curved beams with repeated Dougong, and Chinese caisson ceilings [Figure 2]. Local historical records indicated these churches were constructed before 1900. Among these historic Catholic churches, this paper focuses on a sample of six that were in relatively good conditions [Table 1]. The six churches were selected because they well represented early Catholic church typologies from 1840 to 1900, and their patterns covered different types of Catholic churches, including urban churches, rural churches, and cathedrals. Therefore, did the Catholic churches with traditional Chinese architectural features in East Fujian share some basic patterns? And how were these Catholic churches in East Fujian related to local vernacular buildings?

\section{2. "LONG TERM": THE RELATIONSHIP BETWEEN CATHOLIC CHURCHES AND VERNACULAR BUILDINGS IN EAST FUJIAN}

Catholic missions had expanded to East Fujian long before the First Opium War, and the spread of Catholic Christianity throughout this region had established a solid foundation in the society. During the ban of Christian Missions period, although formal Catholic activities were banned by the Chinese Government, ordinary Catholic activities went to underground. In the view of overall history, the Catholic missions in East Fujian never experienced any interruption or intervention. The earlier missions in the end of Ming dynasty (1368-1644) and the beginning of the Qing dynasty (1644-1911) had formed a solid Catholic foundation in this region, making a critical contribution to the spread of Catholic beliefs and construction of Catholic churches in later period. In the beginning, missionaries tended to rent or buy local dwellings within a dense residential area as the early places for Catholic activities. For example, Angelo Cocchi, an Italian Dominicans missionary purchased a dwelling in Fu'an Chengguan as the first Fu'an Catholic church, which was later confiscated by the Chinese Government in 1724. ${ }^{[4] 363}$ When Emanuel Moreno conducted missions in San-du'ao, Ningde, he converted a dwelling into a church on the San-du Li Street, the earliest Bishop Church at San-du'ao. It was also common for some faithful Chinese Catholics to donate their own dwellings, ancestral halls or temples to become Catholic churches. For example, when a Spanish Missionary PLA (唐巴拉) was missioning at Liuyang Village, he built a church by merging the ancestral temples of three families: Zhang, Zheng, and $\mathrm{Xu}$ together with their surrounding sites. ${ }^{[5]}$ In the meantime, some churches were repurposed into other uses or were used by other religions. For example, there were two churches located at the Nanshan and North Gate of the Xiapua after the Catholic beliefs was introduced in 1635 . However, when the bishop Pierre-Martyr Sanz (白多禄, 1680-1747) was arrested by the government and later was executed at Fuzhou in 1746, most of Chinese Catholics at Xiapu were disaffiliated who later repurposed those two churches into two Daoist temples, called "Nanmen Gong" and "Daotang Gong." ${ }^{[1]}$ Therefore, the building functions switching between Catholic churches and local vernacular buildings at East Fujian had been prevalent for a long time. This flexibility of building use stressed the possibility of the blending and assimilation between the architectural language of Catholic churches and traditional Chinese buildings. The early Catholic churches in East Fujian were not a simple renovation or re-adaption of local vernacular buildings to meet the needs of Catholic activities. Rather, they had accumulated over 200 years of experience in building churches in spite of many times of being destroyed and rebuilt. 

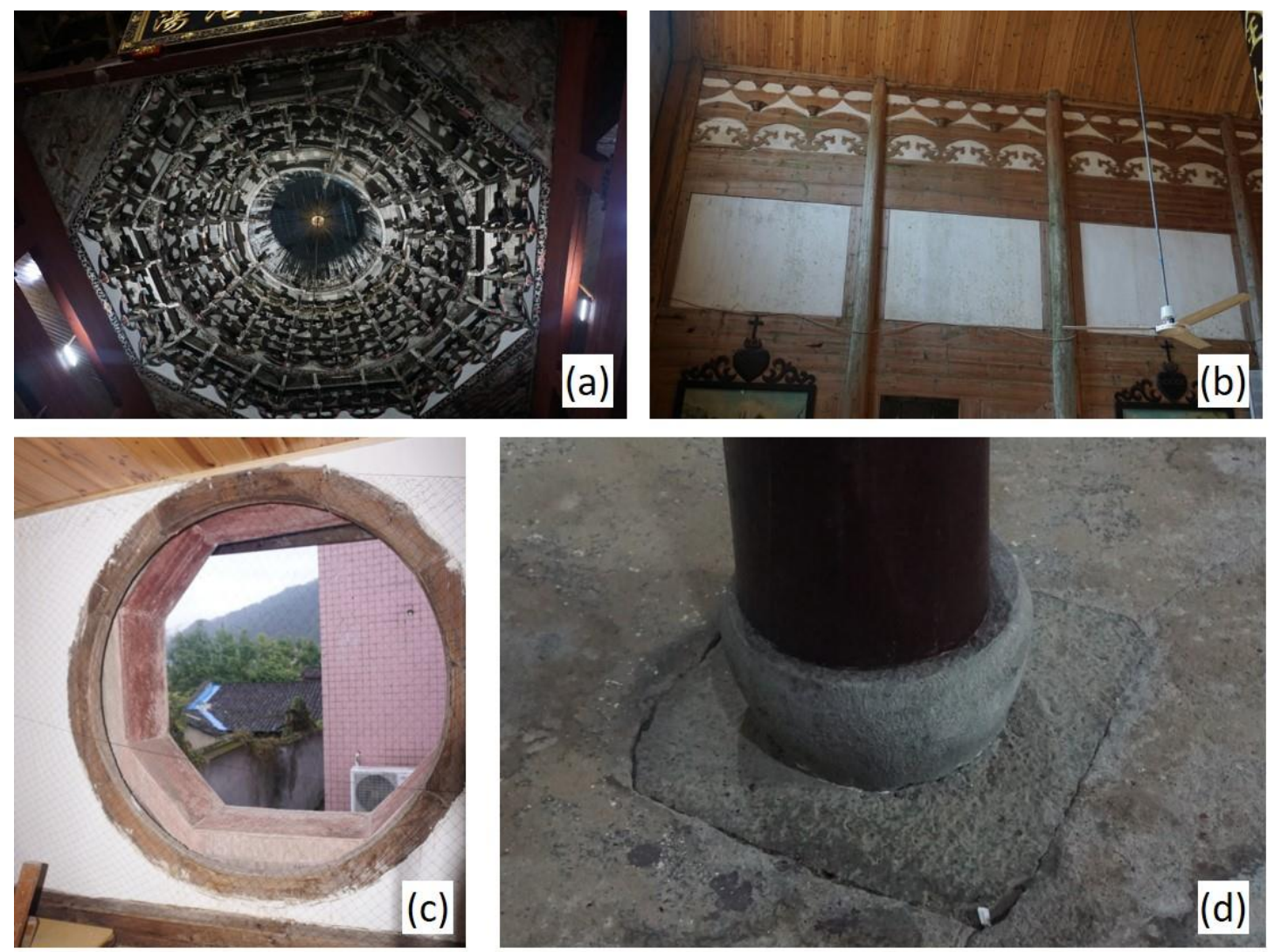

Figure 2. The Chinese and Western characteristics of the Catholic church. (a) Chinese caisson ceiling. (b) Curved beams with repeated Dougong. (c) Moon Window. (d) Column, column base and stone pedestal. Source: Photos by the author

Table 1. Examples of Catholic churches survived today in East Fujian

\begin{tabular}{llllll}
\hline $\begin{array}{l}\text { Name of } \\
\text { church }\end{array}$ & Location & $\begin{array}{l}\text { Original built } \\
\text { date }\end{array}$ & Rebuilt date & Church type & Note \\
\hline Xidong & $\begin{array}{l}\text { Xidong Village, } \\
\text { Chengyang Town }\end{array}$ & 1640 & 1842 & $\begin{array}{l}\text { Cathedral, rural } \\
\text { church }\end{array}$ & Coltell (吴高路德) \\
\hline Lankou & $\begin{array}{l}\text { Lankou Village, } \\
\text { Feiluan Town }\end{array}$ & 1647 & 1848 & Rural church & $\begin{array}{l}\text { Italian Missionary, } \\
\text { Antonio De Santa } \\
\text { Maria Caballero }\end{array}$ \\
\hline Xitian & $\begin{array}{l}\text { Xitian Village, } \\
\text { Xitan Town }\end{array}$ & 1750 & 1850 & $\begin{array}{l}\text { Cathedral, rural } \\
\text { church }\end{array}$ & $\begin{array}{l}\text { Spanish Missionary } \\
\text { (杨埃迪万) }\end{array}$ \\
\hline Yuexiu & $\begin{array}{l}\text { Yuexiu Village, } \\
\text { Xitan Town }\end{array}$ & 1890 & 1890 & Rural church & \\
\hline Muyang & Muyang Town & 1662 & 1889 & $\begin{array}{l}\text { Cathedral, rural } \\
\text { church }\end{array}$ & $\begin{array}{l}\text { Anti-missionary riot } \\
\text { Reparation }\end{array}$ \\
\hline $\begin{array}{l}\text { Hanyang } \\
\text { Chengguan }\end{array}$ & Hanyang Town & 1631 & 1900 & Urban church & $\begin{array}{l}\text { Anti-missionary riot } \\
\text { Reparation }\end{array}$ \\
\hline
\end{tabular}

Sources: "The Chorography of Fujian-Religious Chronicles," "Collection of Historical Documents of East Fujian Catholic Diocese," "Local Chronicles of Ningde Region," "Local Chronicles of Ningde City," "Local Chronicles of Fu'an City," and the author's field studies. 
3. THE "SELECTED" TYPOLOGICAL PATTERNS AND TYPES OF CATHOLIC CHURCHES IN EAST FUJIAN

In the eyes of Western missionaries, combining traditional Chinese architectural elements for Catholic churches was not the only option, but a natural decision. Traditional Chinese architectural elements assisted reducing the cultural gap between local people and Western missionaries and made spatial forms of the churches familiar to Chinese Catholics, which, in turn, would enhance the quality of preaching. As an alien entity seeking a root in Chinese context, Catholic churches inevitably faced many restrictions, challenges and difficulties in finance, resources, and manpower during their early development. In addition, the construction of every church relied on local builders and their skills.

Before the Catholic was imported to China, the architecture of Catholic churches in the West had gone through several thousands of years of evolutions and had formed well-developed patterns. In terms of the floor layout, most churches took the styles of so-called Basilica, Latin Cross, and Greek Cross, among which Basilica and Latin Cross were more prevailing. It was common in most churches' floor plans that there were four major spaces defined, Porch, Nave, Apse, and Altar. The Altar was the spatial core of a church, marking the center of worship and the ending point of the church's longitudinal plan. This spatial arrangement created a linear circulation through the entire church, defining a one-way dynamic space which not only supported all religious needs and functions, but also producing a religiously sacred space.

\section{1 "Selected" by traditional craftmanship}

Based on studies on the floor plans of early churches in Shanghai, some scholars analyzed the evolution of church floor styles from Latin Cross to Basilica, and explained why Basilica became the most prevalent style in China. ${ }^{[6]}$ Considering the same cultural contexts between Shanghai and East Fujian, churches in these two places shared some common features. However, this paper disagreed on the conclusion that the church's floor style evolved from Latin Cross to Basilica. In fact, in early days, different design styles were widely used in churches in the West, and all of them were introduced into China in a short period of time. Although the Latin Cross plan was considered better fit the Catholic liturgical principles and their representations, the Basilica plan, as an early pattern of Western churches, was highly adaptive and easy to be built, which made it a base plan for many churches built in later times.

On the other hand, Christian churches in China were products of architectural collision and interplay between China and the West. When Catholic beliefs were imported into China, it also came with Western styles of Christian architecture and building techniques. In the $19^{\text {th }}$ century, Western architectural styles and building techniques were more advanced and sophisticated than the Chinese ones as many Western nations had been in the process of industrialization while Chinese architecture was still at the manual stage of building and construction. This trans-cultural diffusion led to two-way interplays between Chinese and Western architectures. When one side brought in new building knowledge and techniques, it would result in absorptions and immersions of those knowledge and techniques on the other side. This spread of knowledge and techniques occurred based on the principle of "both the provider and recipient are trying to achieve a balance." ${ }^{[7]}$ In other words, instead of how well the Western missionaries could teach, how well local builders and craftsmen could learn these knowledge and techniques, determined the applications of these knowledge and techniques in China. Therefore, the eventual applications remained certain similarities, not the same, with the original knowledge and techniques. Based on this perspective, the local builders and craftsmen determined the actual architectural typologies of Western Catholic churches in East Fujian. Their learnings, knowledge foundations, and understanding of the 
imported Catholic church architecture made the Basilica plan the major pattern for early Catholic churches in East Fujian, a crucial consequence of the selection and adaption of local architectural contexts. This was substantiated by the fact that all early churches in East Fujian adopted three-aisled Basilica plans.

\subsection{The types of early Catholic churches in East Fujian}

The spatial layouts of churches in the West were controlled by principles of proportions and orders in an organization of spatial modular units, which not only made faster construction possible but also generated rhythmic spaces with repetitions and patterns. The whole floor plan of a church was composed of multiple repeated modular units - the "bay" space, which included two types: single-bay and double-bay. Based on the examination of surveyed building plans of the churches in East Fujian, this study focused on the "bay" space in all floor plans to calculate the ratios of B/A (width of side aisle / width of central nave), C/A (ratio of depth to width of a "bay") for all churches. The results indicated that the naves of the Xidong Church, the Xitian Church, and the Yuexiu Church employed square or quasi-square shapes, while the side aisles of the Lankou Church, the Muyang Church, and the Hanyang Chengguan Church also used square or quasisquare shapes [Table 2]. In terms of the floor plan patterns, the double-bay side aisle (the side aisle's edge wall presented three columns, each of which was smaller than the ones in the nave, shown as $\mathrm{Z} 1<\mathrm{Z} 2$ ) could be discovered in the Xidong Church, the Xitian Church, the Lankou Church, and the Yuexiu Church; and the single-bay side aisle (the side aisle's edge wall presented only two columns, each of which had the same size as the ones in the nave, shown as Z1=Z2) was adopted in the Muyang Church and the Hanyang Chengguan Church. A further study of quantitative analysis on the floor plan patterns concluded that the two different patterns reflected features of two different types of Basilica plans. Compared with churches in the West, churches in East Fujian had similar floor plan patterns (the western groined vaults transformed into Chinese timber-frames), which could be categorized into two plan patterns [Table 3]. Therefore, although the churches in East Fujian were built by traditional Chinese architectural techniques, they were also influenced by Western church patterns, and consequently followed some principles used in the West.

\section{THE RESTRUCTURE AND REINTERPRETATION OF THE PATTERNS OF EARLY CHURCHES IN EAST FUJIAN}

\subsection{Restructuring the patterns: Building within building}

Churches in the West had presented a high cohesion in their interior spaces, structures, and exterior forms. A sound structure made a solid foundation to develop interior spaces and exterior forms. As the place for Catholic collective activities, churches needed a sizable interior space for a large group gathering. When constructing churches, it was always the toughest challenge to build the long-span nave and circular apse, the two most critical structural components.

Table 2. The ratio results of bay spaces in the Basilica plans of early churches in East Fujian

\begin{tabular}{lccl}
\hline $\begin{array}{l}\text { Church } \\
\text { name }\end{array}$ & B/A & C/A & Result \\
\hline $\begin{array}{l}\text { Xidong } \\
\text { Church }\end{array}$ & $1.59: 1$ & $1.37: 1$ & $\begin{array}{l}\text { A quasi-square } \\
\text { nave }\end{array}$ \\
\hline $\begin{array}{l}\text { Lankou } \\
\text { Church }\end{array}$ & $1.65: 1$ & $1.12: 1$ & $\begin{array}{l}\text { A quasi-square } \\
\text { side aisle }\end{array}$ \\
\hline $\begin{array}{l}\text { Xitian } \\
\text { Church }\end{array}$ & $1.2: 1$ & $1.2: 1$ & A square nave \\
\hline $\begin{array}{l}\text { Yuexiu } \\
\text { Church }\end{array}$ & $1.34: 1$ & $1.34: 1$ & A square nave \\
\hline $\begin{array}{l}\text { Muyang } \\
\text { Church }\end{array}$ & $1.52: 1$ & $0.96: 1$ & $\begin{array}{l}\text { A quasi-square } \\
\text { side aisle }\end{array}$ \\
\hline $\begin{array}{l}\text { Hanyang } \\
\text { Chengguan } \\
\text { Church }\end{array}$ & $1.52: 1$ & $1.08: 1$ & $\begin{array}{l}\text { A quasi-square } \\
\text { side aisle }\end{array}$ \\
\hline
\end{tabular}

Note: A, width of naves; B, width of side aisles; C, width of bays 
Table 3. The plan patterns and types of early churches in East Fujian

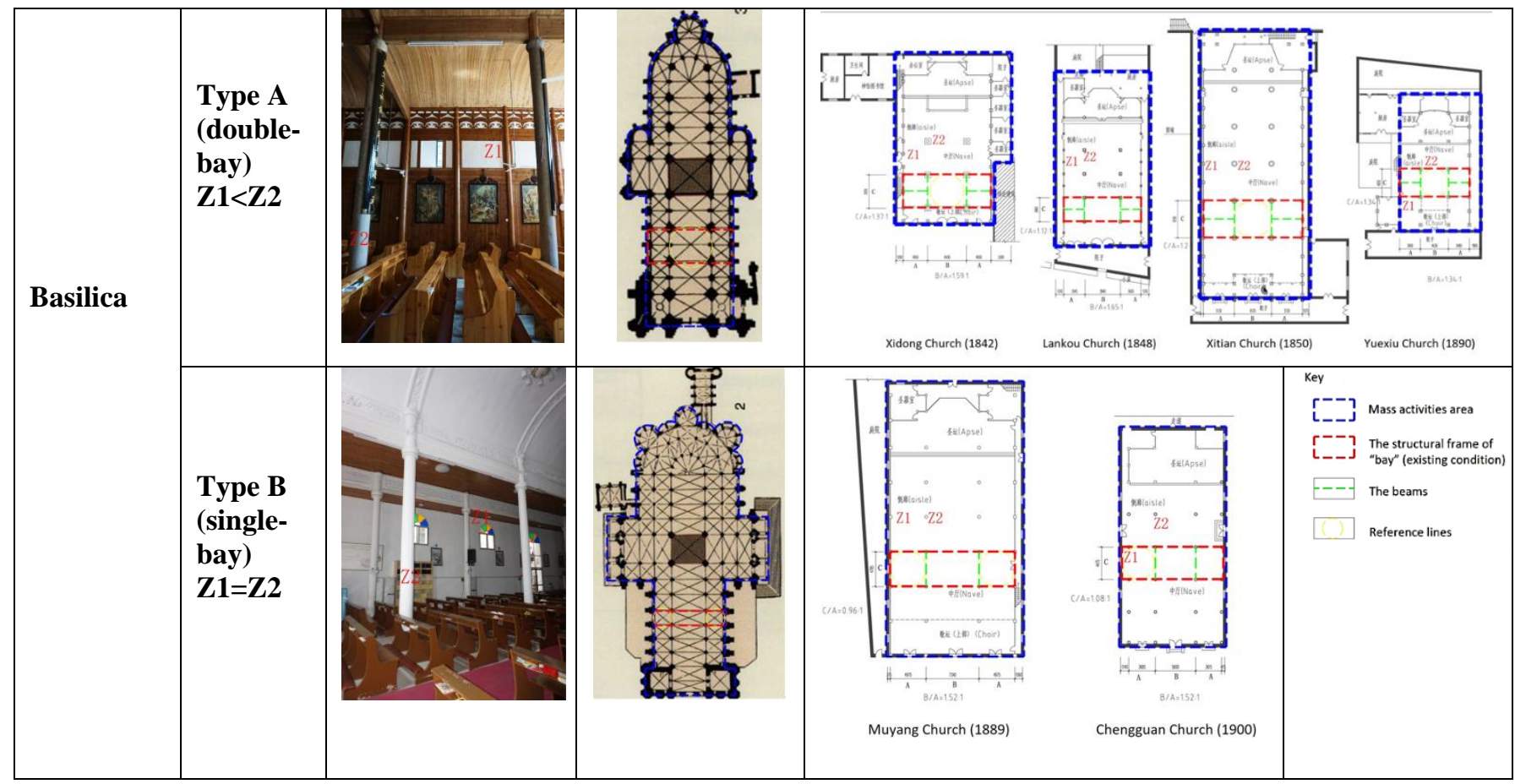

Source: The pattern plans used in this table were from Wang R, The Global History of Architecture: Gothic Architecture. 2008, Chinese Architecture and Building Press, Beijing, pp. 57 (see reference ${ }^{[15]}$ ).

The field studies indicated that the East Fujian Style of beam-inserting-column-body structure were used in the Xidong Church, a once cathedral church originally built in 1842 (with a $14.53 \mathrm{~m}$ long span nave), the Lankou Church, originally built in 1850 (with a 16.4 $\mathrm{m}$ long span nave), and the Muyang Church, originally built in 1889 (with a $17.3 \mathrm{~m}$ long span nave). The Yuexiu Church, a rural church originally built in 1890 , also adopted the local beam-inserting-column-body structure to create a $11.55 \mathrm{~m}$ long interior space in its nave [Figure 3]. This method of building structures, including the ways of structural linkages and details of mortise and tenons, were very similar to those of local dwellings in East Fujian, except that the middle columns were removed to create a longer span space for the naves. ${ }^{6}$ Contrary to the conventional understanding that traditional Chinese buildings only created small span spaces, those evidences demonstrated the timber frame of Chinese column-and-lintel roof structure (beams- inserting-column-body structure) had already provided a good solution of creating longspan interior spaces.

When constructing a church in the West, it was far more challenging to construct the circular apses than to construct the long-span naves. However, the timber-frame structure in traditional Chinese buildings separated walls from weight bearing components, making walls to be curtains and dividers of spaces. For example, in a Chinese timber-frame structure, a fall of a wall would not bring down the entire building. This strategy made it possible to flexibly divide interior spaces so that the rooms were highly adaptive for different uses. The timber-frame structure successfully mitigated the challenges of constructing the apse structures. First, it transformed the shape of apses from circles into polygons to decrease the complexity and cost of construction. Second, it implanted the Basilica-style spatial rules into traditional Chinese gabled walls to form a "building within building" pattern, a restructure of local

\footnotetext{
${ }^{6}$ Please see Figure 6.
} 
vernacular buildings. There were two major features: (a) two independent spatial layers: the inner layer was used to support churches' daily uses, and the exterior layer was the building envelope; (b) a corridor in the middle linked the two layers and used for the church's daily activities. The exterior walls were typically constructed as locally made hollow masonry walls or rammed-earth walls, while the interior walls as plate-board walls. Wooden arches or flat ceilings made by wood boards were widely used as the ceilings of
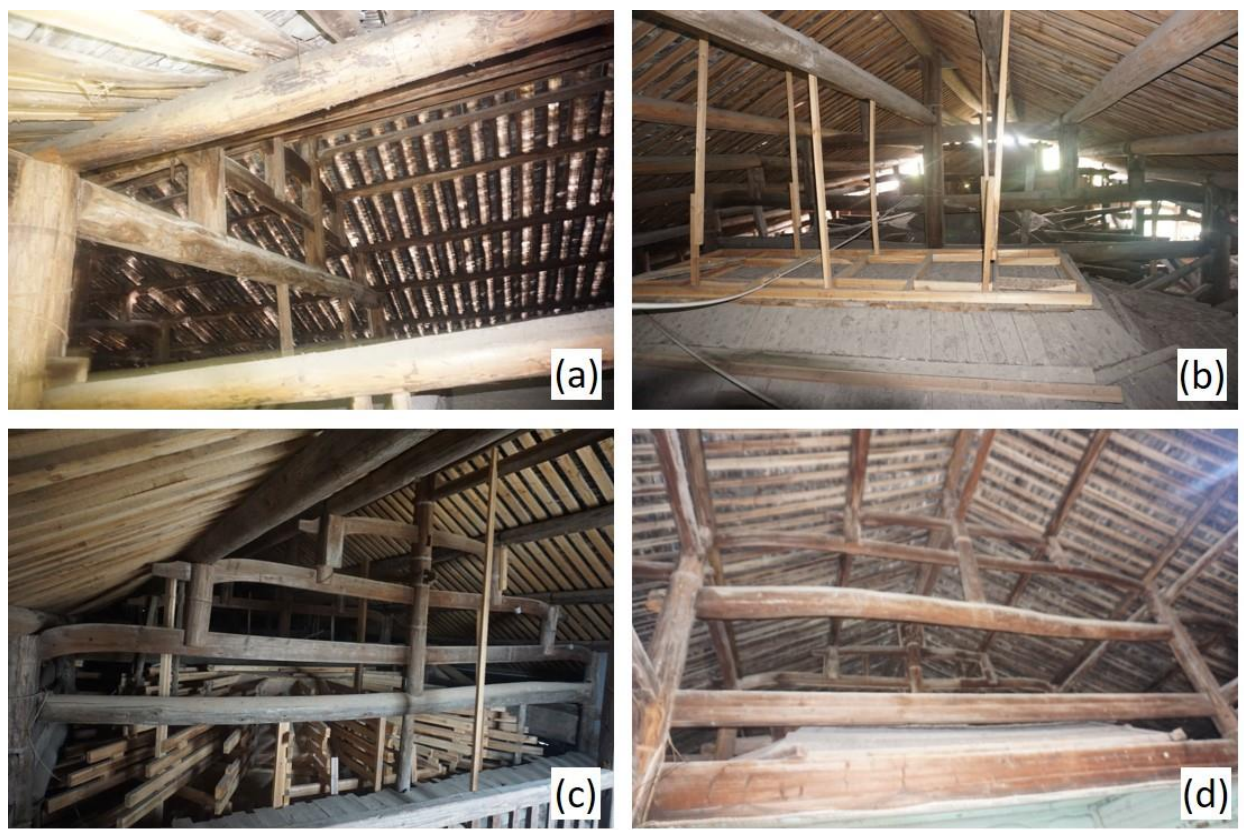

Figure 3. The roof frame structure of Catholic church in East Fujian. (a) The roof frame of the Muyang Church. (b) The roof frame of the Xidong Church. (c) The roof frame of the Xitian Church. (d) The roof frame of Yuexiu Church. Source: Photos by the author

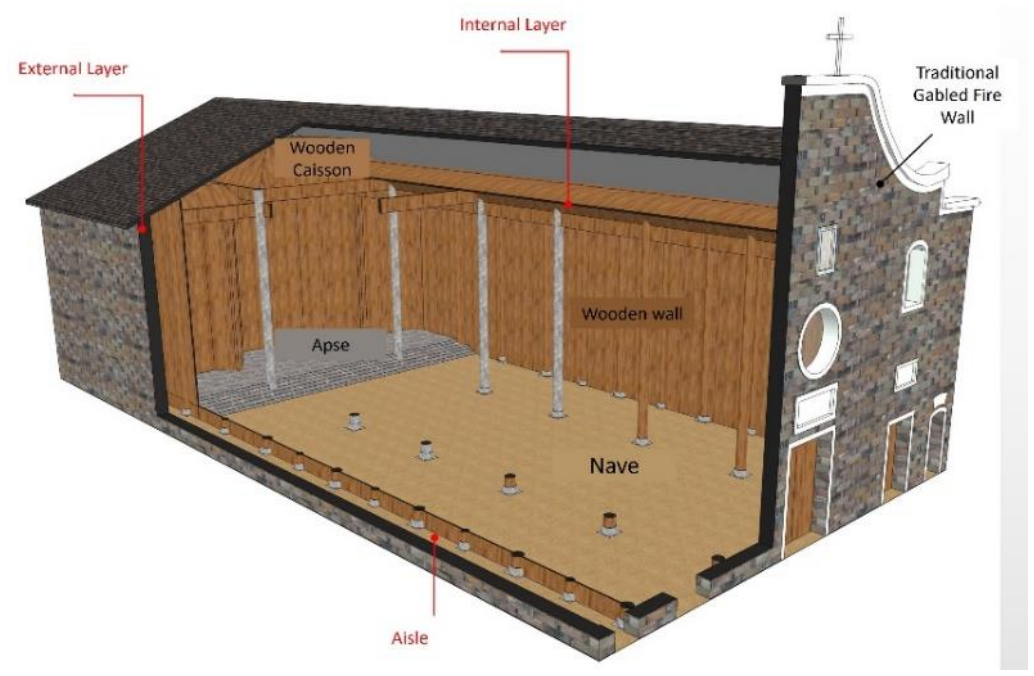

Figure 4. A 3-D diagram showing the building within building in early Catholic churches in East Fujian. Source: Drawing by the author 


\subsection{The isomorphic study of the churches' double-roof system and the traditional hidden sandwiched roof layer}

In the churches in East Fujian, there were two roof layers. Beams at the lower roof layer were processed more elaborately, while beams between the two layers were normally rough processed as they were not exposed to be seen. The lower roof layers were typically made by wood board pieced together on the top of beam joints, connected to other beams by wood suspension bars. There were two types of lower roof layer: one with its form similar to arches in the West, and the other as flat ceilings. The double-roof system in churches in East Fujian indicated the following differences, compared with their counterparts in the West.

(1) Materials - Churches in East Fujian used wood as the primary material for their structures, including columns and beams, while churches in the West mainly used stone for their structures.

(2) Structural systems - Traditional beaminserting-column-body system was primarily used as the structure by churches in East Fujian, while churches in the West employed stone arches for their structures.

(3) Steps of construction - In East Fujian, the construction of churches started the upper roof structure before working on the beams, Dougongs, and ceilings at the lower roof. In churches in the West, the construction of exterior roof structure followed the construction of internal arch structure.

(4) Stress applied on arches - In East Fujian, there were mainly tensile stresses applied to the wood arch structure, which connected to the main structure frame by wood suspension bars, while in Western churches, the stone arches resolved forces into compressive stresses.
(5) Form of roof - In the West, church roofs were presented in different heights, while in East Fujian, the whole church spaces were under one lambdoid-shape roof. In addition, the roof pitches of churches in East Fujian were much smaller than those in the West [Figure 5].

A hidden sandwiched roof layer (also called Jia-Cuo, Fushui Chuan or Xuan) was widely used in vernacular dwellings in Fujian Province. This component was a special kind of ceiling extensively used in dwellings, ancestral halls, and garden buildings in Southern China (including Taiwan), and its construction details were recorded as Cao-Jia in “The Craft of Garden" (《园治》) by Ji Cheng (计成, 1582-1642) of the late Ming dynasty and "Treatise of Original Building Methods” (《营造法原》) by Yao Chengzu (姚承祖，1866-1938) and expanded and edited by Zhang Zhigang (张至刚). ${ }^{7}$ In general, the hidden sandwiched roof layer was a component of a double-layer roof structure for the purpose of dividing spaces, decoration, and heat insulation. In terms of material processing techniques, the hidden part was roughly processed as hidden structural beams, while the exposed part below the hidden layer was elaborately processed as exposed beams. This approach reduced processing time and cost. From the perspective of structural performance, the exposed beams only bore the weight of lower ceiling while the hidden beams bore the weight of the whole roof. Hence, based on the comparison in building materials, structural systems, structural performance of the double-layer roofs, and the approach of building techniques, the churches in East Fujian had many similarities with the vernacular dwellings in Fujian, and consequently, they were isomorphic [Figure $6]$.

\footnotetext{
${ }^{7}$ Multiple scholars have studied this area, such as "The Origination of Cao-Jia" by Cao Xun, "The Typology and Structure of Hidden Sandwiched Roof Layers in Old Buildings in Taiwan" by Li Qianlang, "The History of Chinese Traditional Architecture" by Liu Dunzhen, and a Master thesis "The Form \& Evolution of Xuan in Main Halls of Traditional Buildings in the South Yang Tze River Region During Ming \& Qing Dynasty” by Wang Jia.
} 


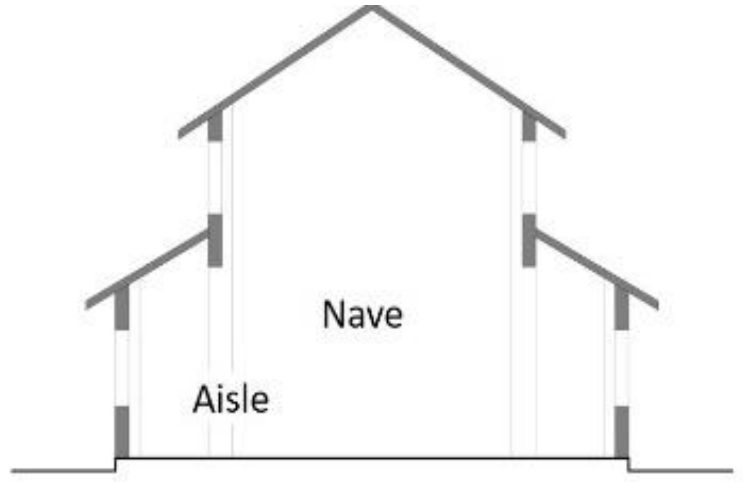

Church in the West

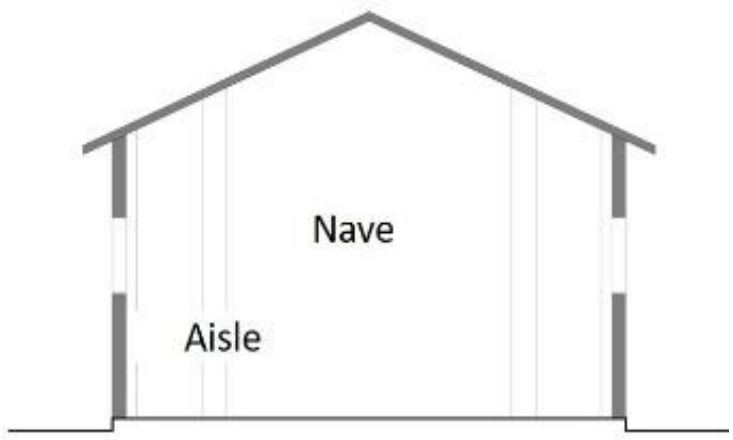

Church in East Fujian

Figure 5. The structural section comparison between churches in the West and churches in East Fujian. Source: Drawings by the author
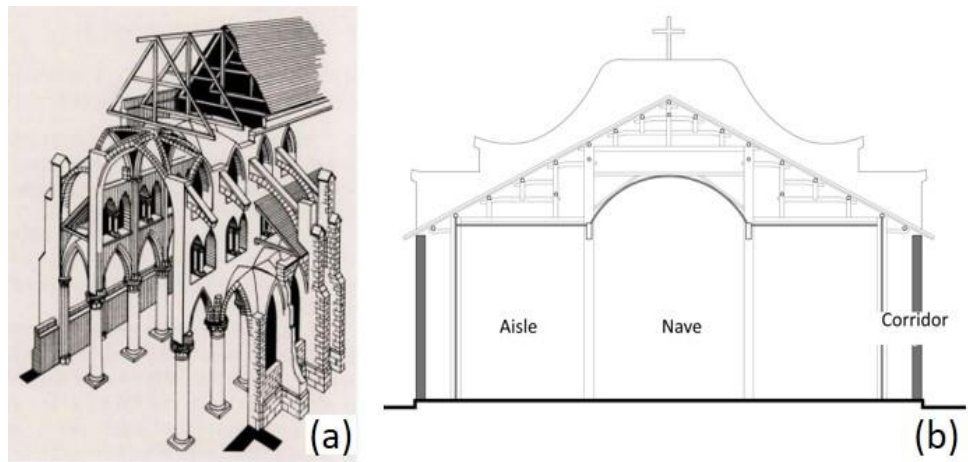

(b)

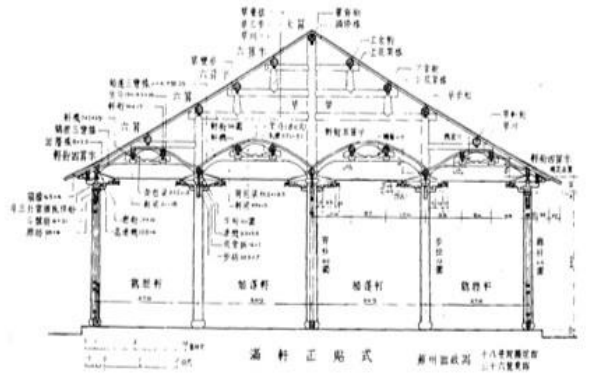

(c)
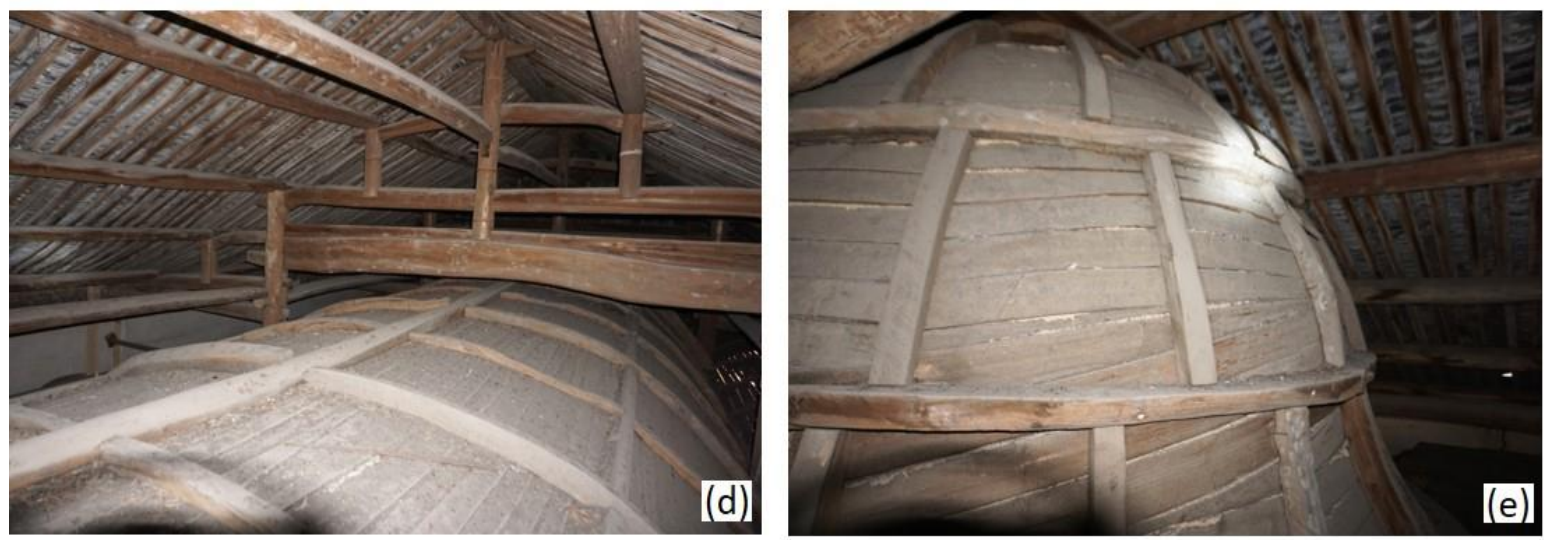

Figure 6. The similarities between Catholic church in East Fujian and vernacular dwellings in Fujian. (a) The section perspective of a typical Basilica church in the West. (b) The section of the timber-frame structure of a typical church in East Fujian. (c) The section of traditional "Xuan" from "Treatise of Original Building Methods." (d) The typical double-layer roof structure found in churches in East Fujian. (e) The typical wooden arch found in churches in East Fujian. Sources: Figure 6(a) from Wang R, The Global History of Architecture: Gothic Architecture. 2008, Chinese Architecture and Building Press, Beijing, pp. 57 (see reference ${ }^{[15]}$ ); Figure 6(c) from Yao C, Zhang Z, Treatise of Original Building Methods (Yingzao Fayuan). 1986, China Architecture and Building Press, Beijing (see reference ${ }^{[20]}$ ); Figure 6(b) is a drawing while Figures 6(d) and 6(e) are photos by the author. 


\subsection{The reinterpretation of the main façade of churches}

Churches in the West were normally located in urban centers, and the main entrance was at the west front, making it the main façade. In general, there was an open space in front of the west front to allow a good view towards the church. When Western missionaries came to China, they developed churches in dense residential areas for the convenience of missions. They attempted to incorporate churches into existing Chinese built environments but faced restrictions of Chinese traditional spatial fabrics of streets and alleyways, which limited the availability of land for church constructions. This could be indicated by the fact that few churches in China had a large open space in front of their main entrances. The church entrances in the West were usually located at the shorter sides of the buildings, while people would commonly go into a traditional Chinese building from its longer side. In order to highlight the main façade with its main entrance, the church in China usually made its longer side perpendicular to major streets according to the site conditions. As a worship place, the orientation of a church represented certain religious rules. Most churches in the West faced east so that the congregation were facing the direction of Jerusalem, the Holy City and the Holy Sepulcher. Therefore, the emphasis of main entrance at the west front contradicted the emphasis of east in Christian belief. Although the Dominican Church severely followed normative Christian rules, and combated heresy, it maintained flexibility in spatial rules when constructing early churches in East Fujian without any reference of building orientation choices [Table 4]. This indicated indirectly that the church main façades were significant in early modern China.

The elevations of old buildings in China were formed by the timber-framed structural system, and were distinct from the façades of buildings in the West. ${ }^{[8]}$ The emphasis of main entrance on the church façades in China contradicted the fact that traditional timberframed structures did not create an emphasis on building façades. As a result, the form of gabled fire walls from local vernacular dwellings were chosen to be the main façades, equivalents to the west fronts with the main entrances of churches in the West. By doing so, gabled fire walls from local vernacular buildings replaced the west fronts to form a new base form of the main façades of churches in China [Figures 7 and 8]. Also, a form of traditional three-bay and two-floor doorway structure was normally implanted into the gabled fire wall front with sculptural decorations made of stones or limes, and couplets hung on the columns of the doors. In the details of building elements, a Chinesestyle moon window was placed in the center of the front façade as the main highlight of the façade, to substitute the rose windows that were often seen in churches in the West. A horizontal stone board, inscribed with two Chinese characters "Sheng Zhi" (referring to Holy Edict), was right above the top of the moon window, demonstrating the legality and legitimacy of Catholic missions [Figure 9].

\section{SUMMARY AND FURTHER DISCUSSION}

This paper has attempted to examine the typologies of early Catholic churches in East Fujian Province, China, to analyze their internal relevance with local vernacular buildings. Focusing on the architectonic and typological connections, this paper has studied the origination of the relevance, the

Table 4. Early churches in East Fujian

\begin{tabular}{lll}
\hline Church name & Orientation & $\begin{array}{l}\text { Facing east- } \\
\text { west }\end{array}$ \\
\hline $\begin{array}{l}\text { Xidong } \\
\text { Church }\end{array}$ & $\begin{array}{l}\text { Northwest } \\
294^{\circ}\end{array}$ & no \\
\hline $\begin{array}{l}\text { Lankou } \\
\text { Church }\end{array}$ & $\begin{array}{l}\text { Northwest } \\
331^{\circ}\end{array}$ & no \\
\hline Xitian Church & North $341^{\circ}$ & No \\
\hline $\begin{array}{l}\text { Yuexiu } \\
\text { Church }\end{array}$ & South $199^{\circ}$ & No \\
\hline $\begin{array}{l}\text { Muyang } \\
\text { Church }\end{array}$ & North $351^{\circ}$ & No \\
\hline $\begin{array}{l}\text { Hanyang } \\
\text { Chengguan } \\
\text { Church }\end{array}$ & Northeast $27^{\circ}$ & No \\
\hline
\end{tabular}



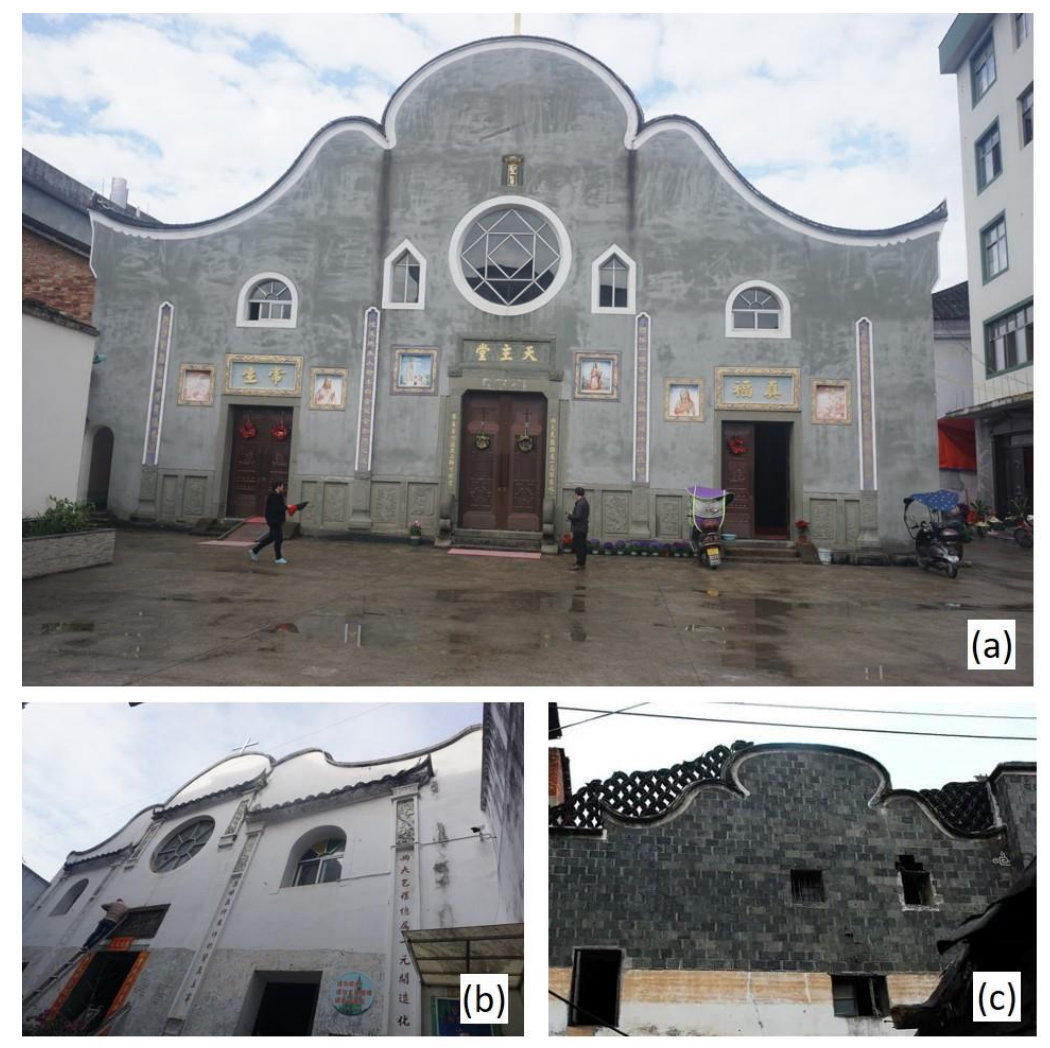

Figure 7. One of the comparisons between the main façade of the church and the gabled fire walls of vernacular dwellings in East Fujian. (a) The main façade of the Muyang Church. (b) The main façade of Hanyang Chengguan Church. (c) The traditional gabled wall in an East Fujian vernacular dwelling. Source: Photos by the author
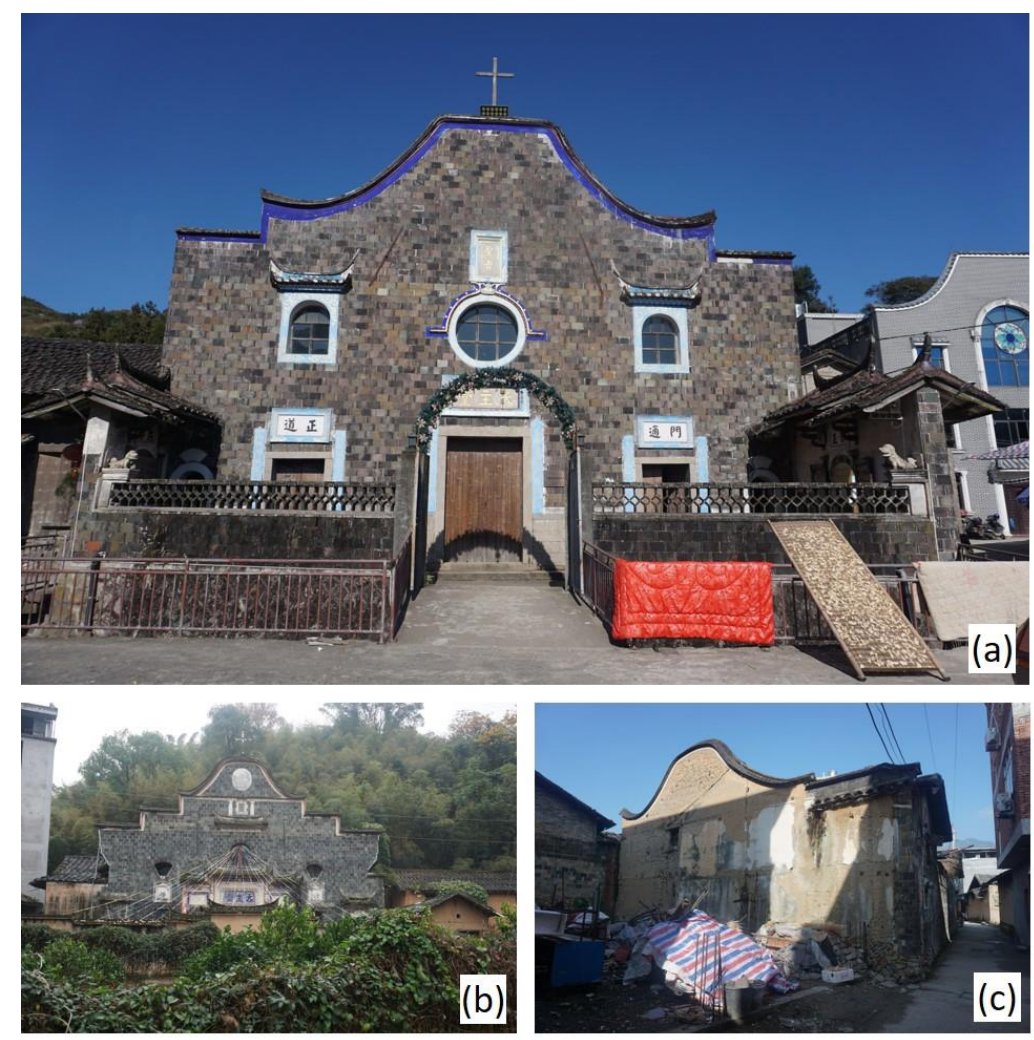

Figure 8. Another comparison between the main façade of the church and the gabled fire walls of vernacular dwellings in East Fujian. (a) The main façade of the Lankou Church. (b) The main façade of Yuexiu Church. (c) The traditional gabled wall in an East Fujian vernacular dwelling. Source: Photos by the author 


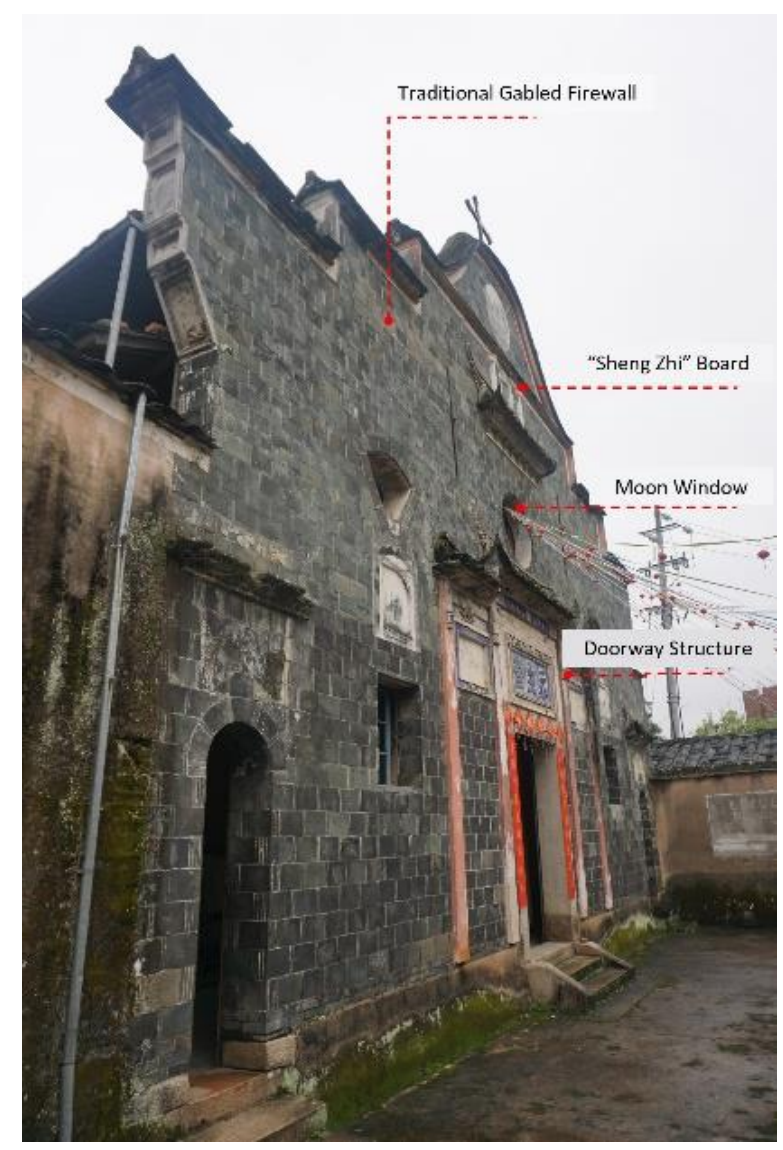

Figure 9. The analysis of basic elements in the main façade of churches. Source: Photo by the author

path of church typological development, and the patterns of church building techniques. The study concludes that both the early Catholic churches in East Fujian Province and local vernacular buildings were based on traditional Chinese craftsmanship, and therefore were isomorphic in building forms. The long-term interplays between the churches in East Fujian and local vernacular buildings remained active, which led to localizing and indigenizing Catholic churches with distinct spatial patterns and features from those in the West. This long-term interplay could be originated back to the approach of "adapting dwellings into churches" in the beginning of Western missions in Fujian. At the time, the original patterns of Catholic churches were filtered by local traditional building techniques in East Fujian. The new patterns were finally achieved based on first decomposing the original Catholic patterns in the West, and then being reinterpreted and reformed by traditional building techniques in East Fujian, all of which were relied on traditional craftmanship system.

In the early modern era, there were mainly two approaches of hybridizing Chinese and Western architectural forms: westernizing traditional Chinese buildings, and indigenizing imported Western styles. The former could be easily found in dwellings, ancestral halls, and widespread stores with western-style storefronts in the coast regions where the homes of most oversea Chinese were located. This approach was usually involved in local craftsmen and sometimes produced forms with arbitrary hybridizations, such as simply adding Western elements into vernacular buildings. The latter could be considered as efforts of reviving Chinese tradition advocated by the movement of "Chinese Inherent Form" in early modern Chinese architecture. ${ }^{[9]}$ The early churches in East Fujian represented the continuous attempts of the localization and indigenization of imported church styles and forms from the West, and a mixture of architecture between China and the West actively facilitated by local craftsmanship system, which made these churches different from those "sinicized churches" driven by the localization of Catholics in China and caused by changes in missionary strategies.. Considering the dimensions of historic and geographic contexts, churches in East Fujian clearly indicated the complexity and diversity of architectural hybridization between China and the West.

Catholic churches in early modern China were produced by architectural clash and interplay between China and the West. Based on a post-colonial view, Catholic churches in China highlighted this architectural dialogue had not been achieved in an equal manner. The Western rules were always more dominant, and therefore became the center of the dialogue. The Chinese rules were less powerful, and therefore were marginalized in the process of interplay, resulting in their contributions to be usually overlooked. Examining the active involvement of 
traditional Chinese architecture in the development Christian churches and their internal relevance would not only improve the understanding of the architectural interplays and engagements between China and the West as a whole, but also enhance the breadth and depth of knowledge in the development of churches in early modern China. By revealing and reevaluating the neglected contributions of traditional Chinese architecture to the development of churches in early modern China, the study of these early churches in the paper would bring benefits to revisit the marginalized history defined by "colonial narratives."

\section{FUNDING}

This study was funded by National Science Foundation of China Research Grants \#51878450 \& \#51738008.

\section{CONFLICT OF INTEREST}

The author declares no conflict of interest.

\section{TRANSLATOR}

Associate Professor Xiao $\mathrm{Hu}$

Architecture Program, College of Art and Architecture, University of Idaho, Idaho, U.S.A.

Email: xiaoh@uidaho.edu

\section{REFERENCES}

[1] Tang J. Local chronicles of Ningde region (Ningde Difangzhi). 1998, Fangzhi Press, Beijing.

[2] Zhang Y. The cultural interplay between China and the West in the case of Catholic missions in Fu'an during the Ming \& Qing dynasty (Cong Mingqingshiqi Tianzhujiao Zai Fu'an De Chuanbo Kan Zhongxiwenhuajiaoliu) [J]. The Journal of Fujian History (Fujian Shizhi), 2006, 2006(1): 25-27, 32.

[3] Li J. The spread and development of Catholic Christianity in East Fujian (Tianzhujiao Zai Mindongdiqu De Chuanbo He Fazhan) [J]. Journal of Ningde Normal College (Philosophy \& Social Science Edition) (Ningde
Shifanxuеyuan Xuebao -Zhexue Shehuikexue Ban), 2000, 2000(1): 46-50.

[4] The Editing Committee of The Chorography of Fujian Province (Fujian Sheng Difangzhi Bianzuan Weiyuanhui). The chorography of Fujian: Religious chronicles (Fujian Shengzhi: Zongjiaozhi). 2014, Xiamen University Press, Xiamen.

[5] Lan J, Lai Y, Lin J. The ethnic study of the Muyun She Ethnic Township in Fu'an (Fuanshi Muyun Shezuxiang Minsudiaocha) [J]. Journal of Ningde Normal College (Philosophy \& Social Science Edition) (Ningde Shifanxueyuan Xuebao - Zhexue Shehuikexue Ban), 2014, 2014(3): 2-13.

[6] Zhou J. The evolution and patterns of floor plans of Shanghai Christian churches in the early modern era (Jindai Shanghai Jiaotangjianzhu Pingmianxingzhi De Yanbian He Moshi) [J]. New Architecture (Xinjianzhu), 2014, 2014(4): 112-115.

[7] Wang B. An analysis of technology endemicity and spread (Jishudiyunxing $Y u$ Jishuchuanbo Wentitanxi) [J]. Studies in Science of Science (Кехиехие Yanjiu), 2002, 2002(4): 353-357.

[8] Zhao C. Misunderstanding of elevations ("Limian" De Wuhui) [J]. Dushu, 2007, 2007(02): 129-136.

[9] Pan G. History of Chinese architecture: The 7th Edition (Zhongguo Jianzhushi). 2015, China Architecture and Building Press, Beijing.

[10] Lin X. Local chronicles of Ningde City (Ningde Shizhi). 1995, Zhonghua Book Company, Beijing.

[11] Lan R. Local chronicles of Fu'an City (Fu An Shizhi). 1999, Chronicles Press, Beijing.

[12] The Editing Group of the Religious Chronicles of Xiapu County (Xiapuxian Zongjiaozhi Bianxiezu). The chronicles of Christianity of Xiapu county (Xiapuxian Jidujiaozhi). 1992, Chronicles Press, Beijing.

[13] Institute of Global Religious Studies, Chinese Academy of Social Sciences 
(Zhongguo Shehuikexueyuan Shijiezongjiao Yanjiusuo). Chinese for Christ: The statistics of Christianity in China 1901-1920 (Zhonghua Guizhu: Zhongguo Jidujiao Shiyetongji). 1987, The Chinese Academy of Social Sciences Press, Beijing.

[14] Wang R. The global history of architecture: Romanesque architecture (Shijie Jianzhushi: Luomanjuan). 2007, China Architecture and Building Press, Beijing.

[15] Wang R. The global history of Architecture: Gothic architecture (Shijie Jianzhushi: Getejuan). 2008, China Architecture and Building Press, Beijing.

[16] Li P. Cross-cultural integration: The indigenization of Church arts in early modern China (Kuawenhua Ronghe: Zhongguo Jindai Jiaotangyishu De Bentuhua Shanbian) [J]. The Study of Western Xia (Xixia Yanjiu), 2014, 2014(1): 64.

[17] Liu D. The history of Chinese traditional architecture (the 2nd Edition) (Zhongguo Gudai Jianzhushi). 1984, China Architecture and Building Press, Beijing.

[18] Cao X. The origination of Cao-Jia (Caijia Liuyuan). In Wang G, He C (Eds). The transactions of Chinese architectural history studies: The 7th Collection (Zhongguo Jianzhushilun Huikan: Diqiji). 2013, China Architecture and Building Press, Beijing, 3-35.
[19] Wang J. The form \& evolution of Xuan in main halls of traditional buildings in the South Yang Tze River region during Ming \& Qing dynasty (Mingqing Jiangnan Tingtangjianzhu Xuan De Xingshi He Yanbian) [D]. 2010, Southeast University, Nanjing.

[20] Yao C, Zhang Z. Treatise of original building methods (Yingzao Fayuan). 1986, China Architecture and Building Press, Beijing.

\section{TRANSLATOR'S NOTE}

See "Most churches in the West faced east so that the congregation were facing the direction of Jerusalem, the Holy City and the Holy Sepulcher. Therefore, the emphasis of main entrance at the west front contradicted the emphasis of east in Christian belief." in section 4.3. The translator considers that they are not in conflict with each other. Rather, the emphasis of the west front is resulted from the need of facing east. It is the west façade of a church as the main front façade that defines a west-to-east circulation and highlights the apse at the east end as the most significant space.

\section{EDITOR'S NOTE}

The author confirms that references [2] and [13] in the primary Chinese version of the article are the same. Thus, the redundant reference has been deleted. 